\title{
CERTAIN FORMS OF EXPRESSION OF JUDICIAL PRECEDENT
}

\author{
Aydar R. Gubaydullin ${ }^{1}$ \\ Valeriya V. Kurnosova ${ }^{2}$
}

\begin{abstract}
The relevance of the studied issues is associated with the increased interaction of the legal systems of our time. The research methodology is based on the dialectic and the systematic approach that follows from it. The article authors take into account the pluralism of the concepts involved in the study. The classic case law is applied to the AngloSaxon legal family. The terms judicial precedent and judicial practice are understood synonymously, but only if the judicial practice is created by the highest judicial instances.
\end{abstract}

Keywords: judicial precedent, judicial practice, law.

\section{Introduction}

The development of the legal system of society is inextricably linked with the evolution of the judicial system, the result of which is the creation of judicial practice that takes on various forms and content in different legal families of modern times. In particular, there are judicial precedents in the Anglo-Saxon legal family, relating to the leading sources of law of this legal family. In the Romano-Germanic legal family, the role of judicial practice is expressed differently; it is an additional source of law.

All this features are described in the theoretical legal and comparative legal literature. At the same time, the answer to the question about the forms of judicial precedent has not received adequate coverage yet. The activity of judicial system, especially the highest judicial instances, is connected with lawmaking, legal regulation, interpretation of law. Therefore, taking into account the peculiarities of the development and interaction of modern legal systems, it is necessary to turn again to the study of this problem.

\footnotetext{
${ }^{1}$ State and Law, Kazan Federal University,, 18 Kremlyovskaya St., Kazan, Republic Tatarstan, 420008, e-mail: aydar8118@gmail.com

2 Department of Theory and History of State and Law, Kazan Federal University,. 18 Kremlyovskaya St., Kazan, Republic Tatarstan, 420008, E-mail: VaVKurnosova@kpfu.ru
} 
Special attention is paid to the peculiarities of judicial practice in the Russian legal system. An extensive palette of the sources of law, the complexity of legal regulation mechanism implies an appeal to the Russian legal experience. The presented article is of a theoretical and legal nature, it can be considered as a basis for carrying out scientific research in other areas of legal science. The research results raise again the question of the relationship between different sources of law.

\section{Methodology}

The theoretical basis of the study consisted of works on comparative law, general theory of law. The methodology of studying the stated problems allows us considering the internal systemic links of a judicial precedent in the context of its structure and content, as well as their external expression, embodied in the forms of judicial precedent.

The purpose, objectives and methodology of the study involve the use of various methods and techniques of scientific knowledge. Analysis, synthesis, analogy provide an opportunity to explore the structure and content of the judicial precedent. Their complex interaction is carried out within the framework of the implementation of structural-functional method. The study of legislation and other sources of law involves the use of formal legal method. Comparison of legal experience in different countries necessitates the use of comparative method of studying legal reality.

\section{Results and discussion}

Understanding the judicial precedent is difficult, as researchers need to take into account the peculiarities of its existence in various legal families of modern times. Here an approach is possible, according to which a general definition of the concept under consideration is proposed, and then its individual features are refined with reference to various legal spaces.

Judicial precedent is a legal text that includes part of the court decision in a particular case, containing information about the rule created by the court, which is interpreted as a generally binding norm of behavior [Arkhipov, Polyakov and Timoshyna, 2012]. From here you can highlight some common signs. 
Firstly, we are talking about an appropriately legalized legal text with a certain structure and content. Secondly, not all the court decision contains information about the general rules of conduct. Thirdly, we are talking not so much about the rule as about the information associated with it. The fact is that, unlike the law, which is immediately created for general legal regulation, a judicial precedent arises as a decision in a particular case, and only later it becomes generally binding. Therefore, fourthly, the judicial precedent contains an implied rule of behavior that may not be explicitly outlined. Its interpretation is a complex logical operation that can be handled by other courts.

Currently, there are various criteria for distinguishing the classification of judicial precedents. However, the most meaningful should be the criterion of their division according to legal force and content, since they reflect the very essence of the judicial precedent. In addition, it is important to make a distinction based on the models of legal systems within which there is a judicial precedent.
135

Judicial precedent in the AngloAmerican legal family encompasses three mandatory principles, namely: stare decisis - principle according to which the observance of precedents is mandatory; ratio decidend - legal position of the judge, which became the legal basis for a decision; obiter dictumauxiliary arguments, referred to as also incidentally said. Thus, at the stage of selecting and analyzing the applicable precedent in the case, the judge, in the course of the law-enforcement process, should distinguish precisely the essence of the decision, separating it from the incidentally said, since the latter does not have binding force. The obiter dictum (incidentally said) may refer to the position of judges in relation to the facts considered on the way in the course of the case, but not relevant to the case on the merits or not having real significance; the position of judges in relation to unacceptable facts; special opinions of judges [Ferencz, 1983].

In addition, judicial precedents are usually classified into creative precedents (original precedent) and interpretation precedents (declaratory precedent) [Shreuer, 1981] in the AngloAmerican legal family. The main 
difference between these two forms is that creative precedents create a fundamentally new rule of law, while interpretative precedents are essentially an act of law enforcement of an existing precedent or charter. In this regard, some authors do not attribute the precedents of interpretation to judicial precedents in their pure form [Bellinger, 2012].

According to the criterion of compliance of the applicable precedent with the files of a particular case, there is binding precedent - it is used if there are no fundamental differences between the precedent and the case under consideration, and applied precedent - it is used when there are significant differences between the precedent and the case, but still used in resolving this dispute [Bradley, 2008]. In addition, correct and incorrect judicial precedents are distinguished. The correct are the judicial precedents formulated by the highest court and the court agrees that the precedent use is correct. The wrong includes judicial precedents, where the court corrects the erroneous application of the rule of law of the previous court. It is believed that in this case the court decision has not become the rule of law
136

[Bankowski., MacCormick., Mo-rawski and Miguel, 1997].

Turning to the continental legal family, it is important to establish that there is no precedent in the understanding of the Anglo-American legal family, but there are independent and distinctive forms of its manifestation.

There are the following forms of judicial precedent in the continental legal family: judicial practice, legal position of the court, explanatory act, act of prejudice [Sinyukov, 2010].

The term judicial practice in modern science is viewed from different angles: as a unity of judicial activity, as a judicial activity in general, as an indicator of the interrelation of legal practice and legal theory. This is due to the fact that judicial practice is a complex and multifaceted phenomenon in its essence.

In this study, the judicial practice is considered as legal provisions and definitions developed during the operation of courts that have a certain commonality and universality, which causes a certain degree of their binding nature. 
Thus, judicial practice is a form of judicial precedent, reflecting the experience of applying the legislation expressed in judicial acts of various levels and being of fundamental importance for similar cases.

The uniformity of judicial practice is an important guarantor of ensuring the stability of legal regulation of public relations and a guarantee for the implementation of the main function of judicial law enforcement - the function of justice.

Based on the objectivity of the legal provisions that constitute the judicial practice, it is necessary to note the current and governing judicial practice.

The current judicial practice is a synthesis of judicial acts of a particular court on a specific issue for a certain (actual) time period.

The leading practice includes the practice of consideration of cases by higher courts, including a review of the current judicial practice of lower courts. The leading practice of the highest judicial instances is formed, among other things, at the meetings of the scientific advisory councils of the highest judicial instances with the participation of judges and legal scholars.

Referring to the example of Russian experience, it is important to note that the violation of the uniformity of judicial practice is the basis for the cancellation or amendment of judicial decisions, which is stipulated by the individual legal acts.

The legal position of the court is considered to be a systematic statement of judgments and opinions of the court instance or court on the motives for the application of a particular legal norm. The legal positions of the court can also be classified by subject, formulating a particular position, and method of its expression.

Regarding the first classification - by subject, formulating the position - we can allocate the following types:

- The individual position of the court. It contains a reasoned justification for the application of a certain rule of law by a judge in a particular case. In addition, we consider it possible to relate the judge's special opinion to the individual position of the court, since it also reflects the judge's opinion on the 
application of a certain rule of law to a specific legal relationship.

- Established positions of the courts. These include such court decisions in which it is possible to single out a systematic, similar assessment of the circumstances of the case and the choice of the applicable rule of law by the courts. It is important to note that even in the territory of one state, it is possible to meet the established positions of the courts that conflict with each other, due to different approaches of the courts to the legal assessment of the actual circumstances of the case. In fact, such a heterogeneous legal assessment of similar legal facts is a negative process, since it gives rise to conflicting legal practice.

In addition, it is important to note the legal positions of the Constitutional Court, which are a source of law in their essence.

According to the form of expression of the court's legal position, the decision (sentence, ruling, resolution) of the court, the decision of the court presidium, the information letters of the court presidiums, the scientific and practical commentary of the court practice, the reviews and other forms are distinguished.

Legal acts are issued by the highest judicial authority based on the analysis of current judicial practice on a particular issue and the established judicial statistics. It should be noted the practical importance of law-enforcement acts as a tool for overcoming legal gaps, ambiguities and legal conflicts, since such acts are an efficient and effective response tool for the purpose of normative regulation within the dynamic social relations. Due to their compulsory compliance by lower courts (as opposed to legal positions that are advisory in nature), this form of judicial precedent causes a lot of discussion about whether such acts are in fact legislative acts or not. Therefore, the law-explaining acts of the highest judicial instances are often referred to as precedents of interpretation. In addition, the explanatory acts can be divided into interpretive acts, which define the understanding of the formal, permanent feature of phenomenon and substantive explanatory acts, which disclose evaluative concepts (conscientiousness, credibility, respectability, etc.). 
In this context, it is important to point out Article 126 of the Constitution of the Russian Federation, as well as Article 19 of the Federal Constitutional Law dated December 31, 1996 On the Judicial System of the Russian Federation, which gives the authority to clarify judicial practice issues to the Russian Supreme Court.

The acts of prejudice include court decisions that have entered into legal force, establishing certain facts and circumstances that do not require proof in the future and are accepted by all judicial bodies as an axiom. As a rule, the acts of prejudice consider such circumstances as the assessment of a regulatory legal act, the competence and status of a state body, the area of legal relations regulated by a specific regulatory legal act, the conformity of regulatory legal acts [Bankowski., MacCormick., Mo-rawski and Miguel, 1997].

In Russian legislation, the status of these acts is reflected in a number of regulatory acts (for example, Article 69 of the Arbitration Procedure Code of the Russian Federation, Article 61 of the Civil Procedure Code of the Russian Federation) as a circumstance precluding proof in a case. We can also note the Resolution of the Plenum of the Supreme Court of the Russian Federation No. 23 dated December 19, 2003 On the Court Decision, which states that the circumstances established by the court decision that have entered into legal force in a previously reviewed case are binding to the court.

The significance of these acts of prejudice is determined by the fact that their absence would give rise to the presence of two contradictory judicial acts for the same legal relations and, accordingly, would give rise to possible risks of revising the same circumstances [Charyev, 2002].

\section{Conclusions}

A comparison of judicial precedent in various legal systems suggests that the features of its manifestation are largely determined by the development and functional role of the phenomenon under study in various legal systems.

Case law has dominated the English legal system for centuries, but the role of legislation began to be strengthened in the XIX century. Judicial precedents were involved in the 
implementation of the regulatory function of the legal system. The law has largely evolved through the activities of legal practitioners [Gubaydullin, 2017].

In the family of civil law, the law was the leading source of law; the judicial practice was related to the interpretation of legislation. However, the recent time was marked by the increasing role of judicial practice.

In modern legal systems, judicial precedent can manifest itself in various forms, which is caused by a significant number of judicial instances at both the international and domestic levels, the expansion of functions of judicial law enforcement, the rapid development of public relations.

As a result, it is seen similarity in the manifestation of individual forms of judicial precedents. There are not only creative precedents, but also interpretation precedents in the family of common law. There are explanatory acts in the continental legal family, in addition to judicial practice. Obviously, these forms have similar features. Legal systems converge, interact, they often have common goals and development objectives. All this causes the similarity of some forms of judicial precedent.

\section{It becomes obvious that} consideration of judicial precedent exclusively as an element of the AngloAmerican legal family is incorrect in modern conditions, since special forms of judicial precedent occur in the continental legal family. Its manifestations such as judicial practice, legal position of the court, legalexplanatory act, act of prejudice are found mainly in the countries of the Romano-Germanic legal family and are important and effective means in the mechanism of legal regulation of social relations.

Summing up, it should be said that the system of legal regulation means created by the variety of manifestations of judicial precedent essentially creates a system of judicial law. The convergence of legal systems, the intensive development of public relations, the expansion of judicial powers make the judicial precedent in its various forms an important source of legal regulation both in the common law system and in the continental legal system. 


\section{Bibliography}

Arkhipo

V.V., Polyakov

A.V.,

Timoshyna E. V. (2012). Adaptation of the Experience of Case Law Systems to the Russian Legal System: to the Problem Formulation. University News. Jurisprudence. 2012. No. 3. P. 117.

Bankowski Z., MacCormick N, Morawski L, Miguel A. (1997). Rationales for Precedent. MacCormick D. and Summers R. (eds.), 1997.- P. 497.

Bellinger J.P., III. (2012). Recognition of Foreign Judgments: Balancing International, Federal, State, and Commercial Interests. Enforcement of Foreign Judgments: 2012 Stefan A. Riesenfeld Symposium. BJIL, 2012.- P. 6.

Bradley C. (2008). Intent, Presumptions, and Non-Self-Executing Treaties / C. Bradley. The American Journal of International Law. 2008. Vol. 102. - P. 541- 546.s[ep?
Charyev M.R. (2002). Judiciary Functions / M.R. Charyev. Justice in the Russian Federation. - 2002. - No. 3. - P. 7-11.

Ferencz B. (1983). Enforcing International Law / B. Ferencz. - Vol. I. - L., 1983.-P.308-317.

Gubaydullin A.R. (2017). Continuity in the Development of Legal System / A.R. Gubaidullin. Bulletin of the University named after O.E. Kutafina (MGYUA). 2017. - No. 3. - Issue Comparative Law. - P. 81-90

Kurnosova V.V. (2017). Judicial Functions: Continuity and Development / Kurnosova V.V.. The Baltic Humanitarian Journal. - 2017. No. 4 (21). - P. 476-478.

Shreuer Ch. (1981). Decisions of International Institutions before Domestic Courts. / Ch.Shreuer. - L. 1981. -P. 143

Sinyukov V.N. (2010). Russian Legal System. Introduction to the General Theory / V.N. Sinyukov - 2nd ed. - M., 2010. - P. 76 